\begin{tabular}{|c|c|c|}
\hline & International Journal of Current Research in & \\
\hline & Biosciences and Plant Biology & \\
\hline $\begin{array}{l}\text { EXCELLENT } \\
\text { PUBLISHERS } \\
\end{array}$ & $\begin{array}{c}\text { ISSN: 2349-8080 (Online) • Volume } 3 \bullet \text { Number } 1 \text { (January-2016) } \\
\text { Journal homepage: www.ijcrbp.com }\end{array}$ & \\
\hline
\end{tabular}

Original Research Article

doi: http://dx.doi.org/10.20546/ijerbp.2016.301.007

\title{
Identification of Wild Indian Elephant Elephas maximus through Species Specific Molecular Markers
}

\author{
S. K. Tiwari*, G. Krishnamurthy, S.S. Yadav, Amit Pandey and Sachin Dixit \\ Forest Genetics, Plant Propagation and Biotechnology Division, State Forest Research Institute, Jabalpur-482 o28, Madhya \\ Pradesh, India \\ *Corresponding author.
}

\author{
Article Info \\ Accepted: 17 December 2015 \\ Available Online: O6 January 2016

\section{Keywords} \\ Elephas maximus \\ Mitochondrial DNA \\ Species specific molecular markers \\ Wildlife forensic
}

\section{Introduction}

The Indian elephant (Elephas maximus) is one of three recognized subspecies of the Asian elephant and native to mainland Asia. Since 1986, Elephas maximus has been listed as Endangered by IUCN The population of majority of wildlife species are declining; some are endangered like The Indian elephant (Elephas maximus) species are already extinct predominantly due to illegal hunting, poaching of elephants for ivory is a serious threat in some parts of Asia. Poaching of tuskers impacts on sex ratios that become highly female biased; genetic variation is reduced, and fecundity and recruitment may decline (Choudhury et al., 2008). Poaching has dramatically skewed adult sex ratios in the Periyar Tiger Reserve, where between 1969 and 1989 the adult male: female sex ratio changed from 1:6 to 1:122 (Chandran et al., 1990). In order to keep a check on dwindling wildlife species, majority of faunal diversity has been protected under different legislations at national as well as international level. In India, most of the species are protected under the Wildlife (Protection) Act, 1972 of India (WPA), which further includes different Schedules and articles based on level of crime committed. While species which are internationally traded, are monitored by regulations of Convention on International Trade in Endangered Species of Wild Fauna and Flora (CITES) In order to strictly enforce WPA, it is necessary to establish a standardize protocol for the identification of species and provide a viable scientific evidence to prove the conviction of crime by offenders (Ogden et al., 1999).

Wildlife crime involves a spectrum of evidence ranging from blood, skin, hairs, tissue/meat, bones, antlers, claws, canines, ivory and miscellaneous wildlife parts and products which may be in finished form. Identification of species from biological samples is an important aspect in wildlife forensics. Some of the evidences like Skin, hairs, antlers etc when intact can be identified using simple microscopic and morphometric techniques and are cost effective. But sample if degraded 
or processed or other sample like, finished wildlife products, urine, saliva, formalin preserved samples, tanned skins etc requires robust techniques over microscopy and morphology to identifying the species (Sahajpal et al., 2010 and Steroid et al., 1995). DNA based species identification relies on successful isolation of genomic DNA from the evidence samples and most of the time, samples sent for forensic DNA examination are degraded or very low in quantity. That affects the efficacy of DNA extraction and PCR amplification of mitochondrial genes. In some cases, samples are preserved in formalin which affects DNA isolation due to forming chemical structures. Formalin preserved samples; the tissue gradually gets a waxy coating of formalin and eventually fixed the tissue sample which in turn inhibits DNA extraction process and it effect negatively to the DNA isolation (Chaw et al., 1980; Paabo et al., 1989; Kosel and Graeber, 1994).

Therefore DNA extraction from the formalin preserved samples is challenging to deal with species identification in wildlife forensic. Selection of the molecular marker that show variation among the species but conserve within the species group is another important factor for DNA based species identification. So mitochondrial region specific, cytochrome $\mathrm{b}$ (Cyt b), 12S ribosomal RNA (12S rRNA), 16S ribosomal RNA (16S rRNA) and cytochrome oxidase subunit I (COI) are commonly used in species identification (Kocher et al., 1989; Meyer, 1994; Mitchell et al., 1993). Mitochondrial genes have specific characteristics as compared to the nuclear gene because there is no recombination in mtDNA, high copy number in cell and show maternally inheritance (Arnason et al., 2002). The present paper describes regarding the identification of Elephas maximus with designing of species-specific primers.

\section{Materials and methods}

\section{Sample collection}

The samples (soft tissue) were collected from Bandhavgarh National Park Madhya Pradesh India and were carefully preserved in silica gel and stored at $-40^{\circ} \mathrm{C}$ in deep fridge.

\section{DNA extraction}

The DNA was isolated from the collected sample (soft tissue) by using the protocol of Diaz-Cano and Brady (1997) with little modification. The treatment of PBS solution was also used in this study.

\section{PCR amplification}

Fragments of DNA were amplified using the species specific primers PCR. All PCR reactions were carried out on Eppendorf EP-gradient Thermal Cycler in a total reaction volume of $20 \mu \mathrm{l}$ containing 1x PCR buffer; 25 $\mathrm{mM} \mathrm{MgCl} 2,10 \mathrm{mM}$ dNTPs, $10 \mu \mathrm{M}$ of each primer, 2.5 U Taq polymerase (Promega) and $2 \mu$ of total DNA. The PCR cycle consisted of following steps: initial denaturation at $94^{\circ} \mathrm{C}$ for $5 \mathrm{~min}$, followed by 32 cycles of denaturation at $94^{\circ} \mathrm{C}$ for 35 seconds, primer annealing at depending on Primer annealing temperature for 45 seconds, primer extension at $72^{\circ} \mathrm{C}$ for 35 seconds, and a final extension at $72^{\circ} \mathrm{C}$ for $10 \mathrm{~min}$. The PCR products obtained were then subjected to electrophoresis on $2 \%$ agarose gel and visualized over an UV transilluminator to assess amplification. Duplicates, negative and positive controls were performed in DNA extractions and PCR amplifications.

\section{Gel electrophoresis}

The Genetix Bioteh Asia Pvt. Ltd. horizontal agarose gel electrophoresis was used for analysis of PCR products. Two percent agarose was used for preparation of gel. For that $2 \mathrm{~g}$ of agarose (Promega USA) was put in $100 \mathrm{ml}$ of $1 \mathrm{x}$ TAE solution (Promega USA) and heated to completely dissolve the agarose. Then $7 \mu$ l ethidium bromide solution was added as gel visualizing agent and mixed thoroughly. The electrophoresis was done for $90 \mathrm{~min}$ at $80 \mathrm{~V}$. The PCR product was finally analyzed using UV transilluminator and documented by gel documentation system (Genetix Bioteh Asia Pvt. Ltd.). The ready to use 100 bp ladders (Promega USA) was used for this studies.

\section{Design of PCR primers}

The oligonucleotide primers were designed against such unique species-specific sites so as to yield appropriately sized PCR products using the "Primer-Select" program (Lasergene software; DNAStar, Inc.). Selected primers were screened for primer specificity (species specificity) and cross reactivity using local alignment tool "BLAST" (http://www.ncbi.nlm.nih.gov/blast). Finally, selected primers were custom synthesized (Integrated DNA Technology) and used for PCR amplification.

\section{Data analysis}

The sequences obtained specimens were compared with sequences available on public domain at GenBank (http://blast.ncbi.nlm.nih.gov/) using BLAST. 


\section{Results and discussion}

Specimen, yield good quality of genomic DNA (Fig. 1A). A sample was amplified with mitochondrial gene (Fig. 1B). The sequences obtained were submitted as independent entries in a BLAST search for the most similar sequences using the default MEGA blast algorithm parameters. For the species diagnosis, we considered the percentage similarity between query and reference sequence pairs (Tables 1 and 2).
The species specific primers used in the present investigation are shown in Table 3. The study reveals that elephant species were identified using molecular forensics techniques, which can produce amplification of spectrum of species and ultimately detect Forensically Informative Nucleotide Sequences (FINS) in closely related organisms. Use of Molecular Forensic techniques would help enforcement agencies for effectively controlling poaching and in better wildlife conservation.

Table 1. Details of used species and GenBank Accession number of used Cytochrome b and 12S ribosomal RNA.

\begin{tabular}{lllll}
\hline S. No & Species & Common name & GenBank & Accession number \\
\hline 1 & Elephas maximus & Elephant & EF 588275.2 & EF 588275.2 \\
\hline
\end{tabular}

Table 2. Similarities in the mitochondrion, complete genome available in GenBank.

\begin{tabular}{llll}
\hline Specimen & $\begin{array}{l}\text { Species with the highest similarity } \\
\text { (GenBank accession in Table 1.) }\end{array}$ & Query coverage (\%) & Similarity (\%) \\
\hline Soft tissue & Elephas maximus & 100.0 & 100.0 \\
\hline
\end{tabular}

Table 3. The details of the elephant specific primers used in the present investigation.

\begin{tabular}{lllll}
\hline $\begin{array}{l}\text { Primer } \\
\text { name }\end{array}$ & Gene & Primer length $(\mathbf{b p})$ & Sequence $\left(\mathbf{5}^{\prime} \mathbf{-} \mathbf{3}^{\prime}\right.$ ) & Primer combination \\
\hline EM K1 & mt genome & 20 & GTCGAATACTCAGCTGGCCC & EM K1 F and EM K1 R \\
& & 20 & GGAACCTCTTGTGACCCTCA & \\
\hline
\end{tabular}

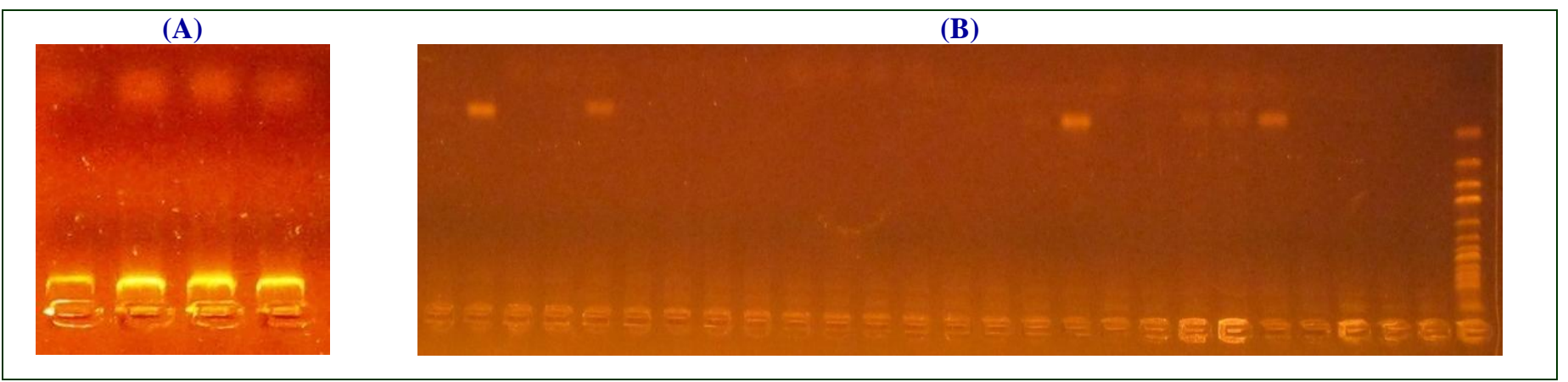

Fig. 1: (A) Quality of DNA; (B) Amplified gel images of DNA fragment with specific primers.

\section{Conclusion}

In conclusion, the elephant specific PCR assay developed in this work presents an easy and reliable single step PCR assay for the identification of elephant. The present work would help in addressing social, religious, economic, forensic and public health issues related to elephant, species identification. Further, it could also be used for routine analysis of suspected samples.

\section{Conflict of interest statement}

Authors declare that they have no conflict of interest.

\section{Acknowledgement}

The authors are very much thankful to Dr. G. Krishnamurthy, Director, State Forest Research Institute (SFRI), Jabalpur (M.P.) India for providing all kind laboratory facilities during the study.

\section{References}

Arnason, U., Adegoke, J.A., Bodin, K., Born, E.W., Esa, Y.B., 2002. Mammalian mitogenomic relationships and the root of the eutherian tree. Proc. Natl. Acad. Sci. USA. 99, 8151-8156.

Chandran, P.M., 1990. Population dynamics of elephants in Periyar Tiger Reserve. In: Proceedings of the Symposium 
on Ecology, Behaviour and Management of Elephants in Kerala (Ed.: Karunakaran, C.K.). Kerala Forest Department, Trivandrum, India. pp.51-56.

Chaw, Y.F.M., Crane, L.E., Lange, P., Shapiro, R., 1980. Isolation and identification of cross-links from formaldehyde-treated nucleic acids. Biochem. 19, 55255531.

Choudhury, A., Lahiri Choudhury, D.K., Desai, A., Duckworth, J.W., Easa, P.S., Johnsingh, A.J.T., Fernando, P., Hedges, S., Gunawardena, M., Kurt, F., Karanth, U., Lister, A., Menon, V., Riddle, H., Rübel, A., Wikramanayake, E. 2008."Elephas maximus". IUCN Red List of Threatened Species. Version 2012.2. International Union for Conservation of Nature.

Diaz-Cano, S.J., Brady, S.P., 1997. DNA extraction from formalin fixed, paraffin-embedded tissues: protein digestion as a limiting step for retrieval of high-quality DNA. Diagn. Mol. Pathol. 6, 342-345.

Kocher, T.D., Thomas, W.K., Meyer, A., Edwards, S.V., Paabo, S., 1989. Dynamics of mitochondrial DNA evolution in animals: Amplification and sequencing with conserved primers. Proc. Natl. Acad. Sci. USA. 86, 61966200.

Kosel, S., Graeber, M.B., 1994. Use of neuropathological tissue for molecular genetic studies: parameters affecting DNA extraction and polymerase chain reaction. Acta Neuropathol. 88, 19-25.
Meyer, A., 1994. Shortcomings of the cytochrome b gene as a molecular marker. Trend Ecol. Evol. 9(8), 278-280.

Mitchell, S.E., Cockburn, A.F., Seawright, J.A., 1993. The mitochondrial genome of Anopheles quadrimaculatus species A: complete nucleotide and organization. Genome. 36, 1058-1073.

Ogden, R., Dawnay, N., McEwing, R., 1999. Wildlife DNA forensics-bridging the gap between conservation genetics and law enforcement. Endang. Spec. Res. 9, 179195.

Paabo, S., Higuchi, R.G., Wilson, A.C., 1989. Ancient DNA and the polymerase chain reaction: the emerging field of molecular archaeology. J. Biol. Chem. 264, 9709-9712.

Sahajpal, V., Goyal, S.P., 2010. Identification of a forensic case using microscopy and forensically informative nucleotide sequencing (FINS): A case study of small Indian civet (Viverricula indica), Sci. Justice. 50, 94-97.

Steroid, B., Fisher, R.A., Khan, I.M., Kessling, A.M., Archard, L.C., 1995. Conserved gene sequences for species identification: PCR analysis of the 3' UTR of the SON gene distinguishes human and other mammalian DNAs. Forensic Sci. Int. 73, 171-178.

\section{How to cite this article:}

Tiwari, S. K., Krishnamurthy, G., Yadav, S.S., Pandey, A., Dixit, S., 2016. Identification of wild Indian elephant Elephas maximus through species specific molecular markers. Int. J. Curr. Res. Biosci. Plant Biol. 3(1), 58-61. doi: http://dx.doi.org/10.20546/ijcrbp.2016.301.007 